\title{
Pengaruh Konsentrasi Larutan dan Durasi Perendaman terhadap Efektivitas Bahan Konservan Poly Etilen Glikol dalam Pelestarian Cagar Budaya Material Kayu (Studi Kasus pada Kayu Waru Gunung)
}

\author{
Yustinus Suranto \\ Fakultas Kehutanan Universitas Gadjah Mada \\ Email: suranto@ugm.ac.id
}

\begin{abstract}
Abstrak: Indonesia memiliki kekayaan cagar budaya berbahan kayu maritim yang sangat besar. Upaya pelestarian dilakukan dengan PEG (Poby-Etilin-Glikol) secara murni dan diterapkan pada perahu kuna Punjulharjo. Keberadaan PEG yang terbatas dan harganya yang mahal mendorong pencarian bahan konservan lain yang banyak tersedia dan murah harganya. Penelitian ini bertujuan mengetahui pengaruh komposisi campuran urea dan PEG sebagai bahan konservan dan durasi perendaman terhadap efektivitas konservasi kayu waru gunung. Efektivitas konservasi diukur berdasarkan parameter stabilitas dimensi kayu.

Penelitian dilakukan dengan prosedur berikut. Empat kelompok contoh uji disediakan, yakni satu kelompok kontrol dan tiga kelompok perlakuan. Disediakan tiga macam konservan campuran urea dan PEG 1000 dengan proporsi 10 dan 10 gram (larutan A1), 20 dan 10 gram (larutan A2), serta 30 dan 10 gram (larutan A3). Kelompok contoh uji direndam dalam larutan konservan dengan durasi perendaman masing-masing 1, 3 dan 5 hari. Penyusutan tangensial, radial, ASE tangensial, ASE radial, jumlah retak, dan panjang retak diukur. Data dianalisis dengan rancangan acak lengkap disusun faktorial dan analisis lanjutan dengan metode beda nyata terkecil (Least Significant Difference).

Hasil penelitian memperlihatkan bahwa proporsi bahan konservan mempengaruhi penyusutan tangensial, penyusutan radial, ASE tangensial dan ASE radial. Semakin tinggi proporsi urea dalam bahan konservan semakin rendah penyusutan tangensial dan penyusutan radial, dan semakin tinggi nilai ASE tangensial dan ASE radial. Lama perendaman kayu dalam konservan mempengaruhi penyusutan tangensial. Semakin lama durasi perendaman semakin rendah penyusutan tangensial. Interaksi antara proporsi bahan konservan dan durasi perendaman berpengaruh terhadap penyusutan radial dan nilai ASE radial.
\end{abstract}

Kata Kunci: Urea, PEG 1000, konservasi, kayu maritim.

\begin{abstract}
Indonesia has many wooden maritime cultural heritage. Cultural heritage preservation by using pure PEG (Poly-Etilin-Glicol) has been done to ancient Punjulharjo boat. Limited PEG availability and its high price has encouraged researcher to search other conservation materials, which are abundantly available and cheap. The study was aimed to determine effect of conservation material made of mixture of urea and poly ethylene glycol and effectiveness immersion duration on conservation of hibiscus wood.

The study was conducted as described in the following steps. Four sample groups consisting of control sample group and three treated sample groups were provided. Three kinds of conservation material made as a mixture of urea and PEG-1000 were provided; each has proportion of 10 and 10 grams (solution A1), 20 and 10 grams (solution A2), and 30 and 10 grams (solution A3). Each of treated sample group was soaked in the mixtures for 1, 3 and 5 days respectively. Tangential and radial shrinkages, tangential ASE, radial ASE, cracks sum and dimension were measured. Data was analyzed by using completely randomized design in factorial arrangement and further testing was done by using Least Significant Difference method.

The results showed that the mixtures have significant effects on tangential and radial shrinkages, tangential ASE and radial ASE. The higher the urea proportion in the mixtures, the lower tangential and radial shrinkages, and the higher the value tangential and radial ASE. The immersion duration has effect on tangential shrinkage. The longer the immersion, the lower the tangential shrinkage value. Interaction of the mixture proportion and immersion duration has effect on radial shrinkage and radial ASE.
\end{abstract}

Keywords: Urea, PEG-1000, cultural heritage conservation, maritime wood

\section{PENDAHULUAN}

\subsection{Latar Belakang}

Indonesia memiliki kekayaan sangat besar dalam

hal cagar budaya berbahan kayu, terutama yang berupa kapal atau perahu, yang berada di wilayah perairan atau maritim. Sudah tentu, cagar budaya ini merupakan suatu warisan yang bernilai sangat tinggi dalam aspek budaya, arkeologi, sejarah, ilmu pengetahuan, teknologi 
dan pendidikan. Pada masa mendatang, aktivitas konservasi terhadap cagar budaya material kayu maritim akan sangat besar dan masif dilaksanakan di berbagai wilayah Nusantara. Oleh karena itu, pengkajian terhadap aktivitas konservasi kayu maritim dan penyediaan sarana, prasarana serta sumber daya manusia yang terampil dalam melaksanakan aktivitas konservasi sangat diperlukan.

Pada tahun 2008, ketika ditemukan perahu kuna di wilayah Punjulharjo Kabupaten Rembang yang berstatus sebagai cagar budaya, maka kepentingan untuk melaksanakan konservasi sangat mendesak untuk segera dilakukan. Pelaksanaan konservasi ini memunculkan problematika dari dua perspektif, baik dari sisi peraturan perundangan maupun dari sisi teknologi konservasi. Dari sisi peraturan perundangan, terlihat bahwa Undangundang Nomor 11 tahun 2010 tentang Cagar Budaya tidak mengijinkan untuk menempatkan dan memperlakukan kayu material cagar budaya sebagai obyek percobaan pada proses konservasi penerapan bahan konservan. Dengan kata lain, menerapkan bahan konservan baru yang belum teruji tingkat efektitasnya secara langsung pada material kayu yang berstatus cagar budaya diusahakan untuk dihindari. Hal ini berkait dengan salah satu prinsip pelestarian yang harus dihormati, yaitu bahwa konservasi harus bersifat reversible (dapat dikembalikan pada kondisi semula).

Dari sisi teknologi pelaksanaan konservasi, terlihat bahwa bangsa Indonesia belum memiliki bekal ilmu dan teknologi serta pengalaman bagi pelaksanaan konservasi cagar budaya material kayu maritim yang pada hakekatnya sangat rentan mengalami degradasi. Dalam rangka mengatasi kendala ini, maka Balai Konservasi Borobudur melaksanakan suatu kajian konservasi kayu maritim, dengan mencoba menggunakan bahan kimia sebagai bahan konservan, yakni poly etilin glikol dan sukrosa (Kusumawati dkk., 2009). Berdasarkan kajian itu, diperoleh kesimpulan bahwa poly etilin glikol merupakan satu bahan konservan yang lebih efektif untuk mengkonservasi kayu maritim, sehingga poli etilin glikol dipilih sebagai bahan konservan bagi pelaksanaan konservasi perahu kuna Punjulharjo (Cahyandaru dkk., 2010)., meskipun disadari bahwa harga poly etilen glikol ini sangat mahal.

Sehubungan dengan berbagai hal tersebut di atas, maka penelitian lebih lanjut tentang pemanfatan poly etilin glikol sebagai bahan konservan perlu dilakukan, terutama menyangkut penentuan parameter-parameter yang berfungsi sebagai tolok ukur penilaian derajat efektivitas hasil konservasi. Di samping itu, penelitian yang berusaha untuk mencari bahan kimia yang harganya relatif murah dan komposisi campurannya untuk digunakan bersama poly etilin glikol sebagai bahan konservan, dan penentuan berapa lama durasi perendaman kayu maritim di dalam bahan konservan juga sangat penting untuk dilakukan.

Penelitian ini bertujuan untuk menguji pengaruh komposisi campuran antara urea dan polietilin glikol sebagai bahan konservan dan durasi perendaman kayu di dalam bahan konservan terhadap efektivitas proses konservasi kayu waru gunung dalam kondisi segar dan berusia muda. Urea dipilih dengan dasar pertimbangan berikut. Urea mudah diperoleh dengan harga yang murah dan dapat digunakan sebagai bahan stabilisasi dimensi kayu. Urea sangat mudah larut di dalam air dan bersifat hampir netral karena memiliki $\mathrm{pH}$ 7,2 pada pelarutannya pada konsentrasi 10\%. Urea memiliki molekul yang cukup besar dan mampu dimasukkan ke dalam kayu dan sekaligus melabur permukaan kayu. Urea bersifat cukup stabil dalam penggunaan maupun dalam penyimpanan. Kayu waru gunung yang berkondisi demikian sengaja dipilih sebagai bahan penelitian karena sifat-sifat yang dimilikinya mendekati sifat-sifat yang dimiliki oleh kayu maritim, yakni memiliki kadungan air sangat tinggi, mengalami penyusutan yang besar, mudah mengalami cacat berupa retak dan pecah.

\subsection{Tujuan Penelitian}

Penelitian ini bertujuan untuk mengetahui: (1) pengaruh komposisi bahan konservan urea dan poli etilin glikol dan pengaruh lama perendaman kayu di dalam bahan konservan terhadap stabilisasi dimensi obyek material kayu yang rentan, (2) menyajikan beberapa parameter sebagai alat pengukur dalam penentuan tingkat keberhasilan konservasi benda cagar budaya maritim, (3) mencari model pengujian untuk menentukan efektivitas penggunaan PEG sebagai bahan konservan dalam aktivitas konservasi Cagar Budaya Material Kayu Maritim. Penelitian ini diharapkan memberikan inspirasi bagi pelaksanaan kajian yang mengarah pada pengukuran tingkat efektivitas bahan konservan bagi konservasi cagar 
budaya berbahan kayu maritim.

\section{STUDI PUSTAKA}

\subsection{Konservasi Cagar Budaya Material Kayu Maritim}

Secara geografis, Indonesia merupakan sebuah kepulauan bahari yang terdiri dari 17.508 pulau dengan garis pantai sepanjang $81.000 \mathrm{~km}$ dan luas laut sekitar 3,1 juta $\mathrm{km} 2$, atau $62 \%$ dari luas teritorialnya. Indonesia berada di antara 2 benua yaitu Asia dan Australia, dan terletak di dua samudra, yaitu India dan Pasifik, sehingga memiliki sumberdaya kelautan yang melimpah. Penelitian terhadap dokumen VOC menyimpulkan, bahwa di wilayah perairan Indonesia ditamukan adanya sekitar 274 situs cagar budaya bawah air, bahkan UNESCO menyatakan, bahwa Indonesia memiliki sekitar 500 situs arkeologi bawah air. Pada situs cagar budaya bawah air terdapat antara lain benda cagar budaya material kayu sebagai hasil kegiatan manusia atau bukti kejadian pada masa lalu. Cagar budaya ini perlu dilestarikan keberadaannya karena memiliki nilai penting bagi sejarah, ilmu pengetahuan, pendidikan, agama, dan/atau kebudayaan melalui proses penetapan. Salah satu benda cagar budaya material kayu maritim yang dilestarikan melalui kegiatan konservasi adalah perahu kuna Punjulharjo yang ditemukan di Rembang (Widianto, 2015).

Upaya untuk mengkonservasi benda cagar budaya material kayu dari lingkungan maritime diwujudkan dengan mengimpregnasinya dengan menggunakan bahan konservan. Banyak jenis bahan kimia sintetik yang dapat digunakan sebagai bahan konservan. Salah satu diantarnya adalah Polietilin Glikol.

Poli-etilin-glikol (PEG) merupakan polimer hasil polimerisasi monomer etilen glikol, sehingga termasuk kedalam golongan polimer sintesis. PEG yang memiliki berat molekul 1000 dinamakan PEG-1000. Rumus molekul PEG adalah $\left(\mathrm{C}_{2} \mathrm{H}_{4} \mathrm{O}\right)_{53} \mathrm{H}_{2} \mathrm{O}$. PEG mempunyai sifat stabil, mudah larut dalam air hangat, tidak beracun, non-korosif, tidak berbau, tidak berwarna, memiliki titik lebur yang sangat tinggi $\left(580^{\circ} \mathrm{F}\right)$, tersebar merata, higoskopik dan juga dapat mengikat pigmen. PEG berupa pasta putih menyerupai lilin atau paraffin. Berupa bentuk padat pada suhu kamar, mencair pada suhu $104^{\circ} \mathrm{F}$. Harga PEG sangat mahal. PEG digunakan sebagai bahan utama yang digunakan dalam proses konservasi kayu melalui mekanisme proses stabilisasi dimensi. Penggunaan PEG 600 sampai dengan 4000 sangat efektif sebagai bahan konservan bagi kayu arkeologi dari lingkungan maritim (Hafors, 2010).

Di samping PEG, ada bahan sintetik lain yang berpotensi digunakan sebagai bahan konservan, salah satunya adalah Urea. Urea merupakan bahan senyawa organik pertama yang dibuat dari bahan anorganik. Urea merupakan senyawa yang sangat mudah larut di dalam air. Pada pelarutannya di dalam air pada konsertrasi 10\%, urea memiliki pH 7,2. Urea bersifat cukup stabil dalam penggunaan maupun dalam penyimpanan. Apabila terkena suhu tinggi, urea akan terdekomposisi dan menghasilkan senyawa amonia, nitrogen oksida, asam sianurik, asam sianida, biuret dan karbon dioksida.

Urea dapat digunakan sebagai bahan stabilisasi dimensi kayu. Harga yang murah dan tingkat kemudahannya untuk diperoleh mendorong pemanfaatan urea semakin intensif sebagai bahan stabilisasi dimensi kayu bersama dengan PEG. Urea memiliki molekul yang cukup besar dan mampu dimasukkan ke dalam kayu dan sekaligus melabur permukaan kayu (Kadir, 1977).

Pemanfaatan bahan konservan yang terdiri atas campuran antara urea dan PEG dengan perbandingan 3:1 dan pada durasi perendamaan selama 3 hari ternyata menghasilkan tingkat stabilisasi dimensi yang positif terhadap kayu suren (Toona sureni Merr) yang ditandai dengan angka penyusutan tangensial dan radial yang rendah, yakni 4,33\% dan 2,86\% (Fernando dan Prayitno, 1999).

\subsection{Perubahan Dimensi Material Kayu}

Kayu merupakan material yang bersifat higroskopis. Sifat higroskopis berarti bahwa kayu mengabsorbsi (menyerap) air apabila kayu berada pada lingkungan yang kelembaban udaranya lebih tinggi daripada kelembaban kayu. Sebaliknya, kayu mendesorbsi (melepaskan) air bila kayu berada pada lingkungan yang kelembaban udaranya lebih rendah daripada kelembaban dirinya. Sifat higroskopis ini menghadirkan konsekuensi, bahwa di dalam kayu selalu terdapat air. Keberadaan air di dalam kayu dapat dikelompokkan menjadi dua kelompok status, yaitu air bebas dan air terikat. Air bebas adalah air yang berada di dalam rongga sel kayu, sedangkan air terikat adalah air yang berada pada dinding sel kayu 
(Shmulsky dan Jones, 2011).

Ketika kayu mendesorbsi air, maka air bebas akan keluar lebih dahulu, kemudian baru diikuti oleh keluarnya air terikat meninggalkan kayu. Sebaliknya, bila kayu mengadsorbi air, maka air masuk ke dalam kayu dan menempati dinding sel kayu sehingga berstatus sebagai air terikat. Setelah dinding sel mengalami kondisi jenuh, masuknya air ke dalam kayu akan mengisi bagian rongga sel kayu, yakni sebagai air bebas. Akibat sifat desorbsi ini, maka suatu saat tertentu, tercapai suatu kondisi tertentu kayu, yang pada kondisi ini, air bebas tidak lagi terdapat di dalam kayu karena air ini telah sepenuhnya keluar meninggalkan kayu, sedangkan air terikat masih dalam kondisi penuh dan baru akan mulai keluar meninggalkan kayu. Pada kondisi yang demikian ini, kayu disebut sebagai kayu yang berstatus titik jenuh serat (TJS). Dalam kondisi titik jenuh serat, kayu memiliki kadar air 27\%. Bagi jenis kayu tertentu, kondisi TJS tercapai pada kadar air 30\% (Kollman dkk., 2012)

Status TJS merupakan status yang penting bagi kayu karena berkaitan dengan perubahan dimensi kayu. Proses absorbsi air yang berlangsung pada kayu ketika kayu itu memiliki kandungan air di bawah status TJS, maka absorbsi itu akan diikuti dengan pertambahan dimensi kayu. Artinya, kayu akan mengembang. Proses absorbsi kayu yang berlangsung pada kayu ketika kayu itu mengandung air di atas TJS, maka proses absorsi ini tidak lagi diikuti dengan pengembangan dimensi kayu. Sebaliknya, proses desorbsi kayu yang berlangsung pada kayu ketika kayu itu mengandung air di atas TJS, maka proses desorbsi tidak diikuti dengan penyusutan dimensi kayu. Proses desorbsi air lebih lanjut yang berlangsung pada kayu ketika kayu itu memiliki kandungan air di bawah status TJS, maka desorbsi itu akan diikuti dengan pengurangan dimensi kayu. Artinya, kayu akan menyusut ukurannya (Kollman dkk., 2012)

Penyusutan dimensi kayu akibat proses desorbsi di bawah TJS berlangsung secara tidak sama besarnya pada setiap arah sumbu pohon. Penyusutan dalam arah sumbu tangensial lebih besar daripada penyusutan dalam arah radial. Penyusutan yang berlangsung dalam arah sumbu longitudinal merupakan penyusutan paling kecil. Besarnya nilai penyusutan yang berbeda-beda pada setiap sumbuh pohon ini memperlihatkan adanya sifat anisotropi kayu. Adanya perbedaan nilai penyusutan antara penyusutan arah sumbu tangensial dan penyusutan radial ini menyebabkan adanya cacat dan kerusakan pada kayu, baik berupa cacat retak, pecah bahkan terbelah (Shmulsky dan Jones, 2011).

\subsection{Stabilisasi Dimensi Kayu}

Stabilisasi dimensi kayu merupakan suatu proses yang bertujuan untuk menahan laju perubahan dimensi kayu dalam wujud penyusutan kayu. Ada lima prinsip dasar yang menjadi landasan bagi stabilisasi dimensi kayu. Kelima prinsip dasar tersebut meliputi hal berikut. Pertama, menghalangi penyerapan air oleh kayu dengan cara pelapisan kayu. Kedua, menghalangi perubahan dimensi kayu dengan cara penahanan pada tingkat sel. Ketiga, mengganti air terikat dan air bebas di dalam kayu dengan bahan lain yang stabil. Keempat, memperlakukan kayu untuk menghasilkan hubungan silang antara kelompok hidroksi dalam dinding sel kayu. Kelima, pengisian kayu dengan monomer yang berbasis material plastik.

\subsection{Penilaian Tingkat Keberhasilan Konservasi Kayu Maritim}

Konservasi cagar budaya kayu maritim perlu dipelajari baik menyangkut fenomena yang terjadi dalam proses konservasi maupun tanggapan kayu itu setelah dikenai proses konservasi. Keberhasilan proses konservasi kayu maritim perlu diukur terutama mengenai stabilitas dimensi kayu maritim tersebut. Penilaian tingkat keberhasilan stabilisasi dimensi kayu maritim dilakukan dengan beberapa aspek, yaitu derajat stabilisasi dimensi, perbedaan sifat-sifat kayu setelah distabilisasikan dan beaya yang diperlukan dalam proses stabilisasi dimensi. Tinggi rendahnya tingkat stabilisasi dimensi dipengaruhi oleh jenis bahan konservan dan durasi waktu yang diterapkan pada perendaman kayu dalam rangka pelaksanaan proses stabilisasi dimensi.

Derajat stabilisasi kayu yang dicapai dalam proses stabilisasi dimensi kayu diukur dengan beberapa parameter, yaitu penyusutan tangensial, penyusutan radial, ratio penyusutan tangensial dan radial (ratio T/R), serta Anti Shrink Effisiensi (ASE) tangensial dan ASE radial (Kollman dkk., 2012). ASE adalah nilai yang menunjukkan perbandingan antara selisih nilai penyusutan kayu sebelum dan sesudah proses stabilisasi 
dimensi dengan nilai penyusutan total kayu yang tidak distabilisasikan, yang dinyatakan dalam persen. Hasil penilaian didasarkan pada kriteria berikut. Proses stabilisasi dinilai semakin berhasil bila ditunjukkan oleh semakin rendahnya nilai penyusutan tangensial dan radial, ratio $T / R$ semakin mendekati angka 1 dan semakin tingginya persentase nilai ASE.

\subsection{Kayu Waru Gunung sebagai Obyek Penelitian}

Pohon waru gunung (Hibiscus macrophyllus Roxh) mampu tumbuh pada tempat yang berketinggian 1 sampai dengan $1400 \mathrm{~m}$ di atas permukaan luat. Pohon ini tumbuh pada wilayah dengan sebaran geografis sangat luas, yakni pada pulau-pulau: Sumatera, Jawa, Kalimantan, khususnya bagian selatan dan timur. Oleh karena itu, pohon ini memiliki banyak nama lokal sesuai dengan kelompok etnik yang habitat hidupnya juga menjadi tempat tumbuh bagi pohon tersebut. Kayu ini diberi nama: anuk-anuk oleh etnik Batak Karo; tesuk, tisuk dan tisuk tembaga oleh etnik Sunda. Sementara itu, masyarakat etnik Jawa menyebutnya dengan nama waru gombong, waru lanang, waru payung, waru batang atau waru.

Sifat-sifat kayu waru gunung adalah sebagai berikut, dalam konteks sifat kimia, maka kadar ekstraktif larut dalam air dingin 2,61\% dan dalam air panas 8,13\% dan dalam alkohol-benzena 2,71\%. Kadar holoselulosa, alfa-selulosa, lignin dan pentosan secara berurutan adalah 75,80; 45,12; 21,92 dan 27,49\%. Dalam konteks sifat anatomi, maka panjang serat 1,29 $\mathrm{mm}$, diamter serat 16,70 mikron, diamter lumen 11,87 mikron dan tebal dinding sel 2,55 mikron (Setiawan, 2001). Dalam konteks sifat fisika, kayu kondisi segar ini memiliki kadar air 77,90\%, berat jenis 0,42, penyusutan tangensial $6,30 \%$ dan penyusutan radial 3,84\% Dalam konteks sifat mekanika, kayu ini memiliki kekuatan tekan sejajar serat 398,34 kg/ $\mathrm{cm}^{2}$; kekuatan tekan tegak lurus serat $210,87 \mathrm{~kg} / \mathrm{cm}^{2}$, kekuatan geser 408,36 kg/ $\mathrm{cm}^{2}$; kekerasan bidang tangensial $255,13 \mathrm{~kg} / \mathrm{cm}^{2}$, kekerasan bidang radial $266,14 \mathrm{~kg} / \mathrm{cm}^{2}$ dan kelenturan $92.600 \mathrm{~kg} / \mathrm{cm}^{2}$ (Noer, 2001). Kayu ini cenderung memiliki dimensi tidak stabil. Kecenderungan ini ditandai dengan ratio penyusutan tangensial dan radial yang nilainya hampir mendekati angka 2. Dengan demikian, kayu ini mudah mengalami cacat berupa retak, pecah dan terbelah. Kayu ini juga tergolong kelas kayu berkekuatan sedang, demikian pula tingkat kelenturannya (Anonim, 1976).

\section{METODOLOGI PENELITIAN}

\subsection{Bahan dan Alat}

Penelitian ini menggunakan Poli-elitin-glikol, urea, air suling dan kayu segar dari jenis pohon waru gunung (Hibiscus macrophyllus Roxb). Tiga batang pohon waru gunung yang berumur lebih kurang 15 tahun ditebang dari wilayah Magelang.

Peralatan yang diperlukan dibedakan menjadi dua kelompok. Kelompok pertama digunakan untuk menebang pohon dan membuat contoh uji, yakni meliputi gergaji rantai STIHL, gergaji pita, gergaji lingkar, pita ukur, dan mesin pengampelas kayu. Kelompok kedua digunakan untuk melakukan pengujian di laboratorium, yakni meliputi kaliper digital 0,01 cm, timbangan analitis, desikator, gelas ukur, pengaduk dari bahan kaca dan gelas piala untuk perendaman contoh uji, serta tanur pengering.

\subsection{Tempat Penelitian}

Penelitian dilaksanakan di dua laboratorium, yaitu (1) Laboratorium Pengeringan dan Pengawetan Kayu dan (2) Laboratorium Penggergajian dan Pengolahan Kayu pada Bagian Tenologi Hasil Hutan Fakultas Kehutanan Universitas Gadjah Mada.

\subsection{Prosedur Penelitian}

Proses penelitian dilakukan dengan prosedur sebagai berikut.

1. Tiga pohon sehat waru gunung ditebang. Contoh uji berupa empat persegi panjang dibuat berukuran $3 \mathrm{~cm} \times 3 \mathrm{~cm} \times 1,5 \mathrm{~cm}$ berurutan dalam arah sumbu tangensial, radial dan longitudinal sebanyak 12 buah dari setiap batang pohon, sehingga secara keseluruhan diperoleh 36 buah contoh uji.

2. Seluruh contoh uji direndam dalam air suling selama seminggu agar menjadi jenuh air.

3. Tiga macam larutan konservan dibuat, yaitu larutan A1, A2 dan A3, yang masing-masing merupakan campuran antara urea dan PEG-1000 dengan proporsi yang berbeda, yakni 10 dan 10 gram (larutan A1), 20 dan 10 gram (larutan A2), serta 30 dan 10 gram (larutan A3).

4. Contoh uji sebanyak 9 buah dipindah dari perendaman 
dalam air suling menuju ke dalam larutan A1, 9 buah yang lain ke dalam larutan A2, dan 9 buah yang lain lagi ke dalam larutan A3, serta 9 buah selebihnya ke dalam air suling.

5. Tiga buah contoh uji dipindah dari perendaman dalam larutan A1 setelah perendaman berlangsung selama 1 hari, 3 buah contoh uji lainnya dipindah setelah perendaman selama 3 hari, dan 3 buah contoh uji selebihnya dipindah setelah perendaman berlangsung selama 5 hari. Pola pengentasan contoh-contoh uji dari larutan A1 itu juga diterapkan bagi contohcontoh uji yang direndam dalam larutan A2, larutan A3, dan air suling.

6. Dimensi masing-masing contoh uji pada sisi tangensial dan radial diukur sesegera mungkin setelah dientaskan dari perendaman.

7. Seluruh contoh uji dikeringkan di dalam oven yang diatur dengan pola penaikan suhu secara bertahap sehingga mencapai $103 \pm 2^{\circ} \mathrm{C}$, kemudian dimensi contoh uji diukur pada sisi tangensial dan radial serta dimensi retak yang dialami contoh uji setelah dua jam pengeringan. Pengeringan selama dua jam yang diikuti dengan pengukuran itu dilakukan secara berulangulang sampai contoh uji tersebut mencapai dimensi yang konstan.

8. Nilai penyusutan tangensial, penyusutan radial dan nilai ASE (Anti Shrink Effisiensi) dihitung. Nilai penyusutan dihitung dengan rumus: $\mathrm{Sh}=\{(\mathrm{D} 1-\mathrm{D} 2) /$ D1 $* 100 \%$, sedangkan nilai ASE dihitung dengan rumus: $\mathrm{ASE}=\{(\mathrm{U}-\mathrm{T}) / \mathrm{U}\} * 100 \%$. Konotasi huruf yang ada di dalam rumus adalah sebagai berikut. D1 adalah dimensi contoh uji saat dientaskan dari perendaman larutan konservan. D2 adalah dimensi contoh uji dalam kondisi kering tanur. $U$ adalah nilai penyu-sutan contoh uji yang tidak direndam dalam larutan konservasi. $\mathrm{T}$ adalah nilai penyusutan contoh uji setelah direndam dalam larutan konservan.

\subsection{Analisis Hasil Penelitian}

Penelitian ini menerapkan dua faktor perlakuan, yaitu komposisi bahan konservan dan durasi perendaman di dalam larutan konservan. Komposisi bahan konservan dibedakan menjadi tiga aras, yaitu campuran antara urea dan PEG dengan perbandingan 10:10 gram (A1), dan $20: 10$ gram (A2), serta $30: 10$ gram (A3). Durasi perendaman kayu dalam bahan konservan juga dibedakan menjadi tiga aras, yaitu perendaman selama 1 hari, 3 hari dan 5 hari. Setiap kombinasi perlakuan dilakukan dengan tiga kali ulangan. Dengan demikian, maka data dianalisis dengan menggunakan rancangan rancangan acak lengkap yang disusun secara faktorial. Bila ditemukan adanya perbedaan nilai pada aras perlakuan maupun interaksi, maka dilakukan pengujian lanjutan dengan menggunakan analisis beda nyata terkecil (Least Significant Difference = LSD).

\section{HASIL PENELITIAN DAN PEMBAHASAN \\ 4.1 Hasil Penelitian}

Penelitian ini melibatkan pengamatan terhadap 7 parameter, yaitu : (1) penyusutan tangensial, (2) penyusutan radial, (3) rasio penyusutan $T / R$, (4) ASE tangensial, (5) ASE radial, (6) jumlah retak, (7) panjang retak. Hasil penelitian secara agregatif disajikan dalam Lampiran 1.

\subsection{Analisis Hasil}

Pengaruh komposisi bahan konservan dan lama perendaman terhadap setiap parameter penelitian dapat diketahui dengan melakukan analisis varians. Hasil analisis varians secara detil disajikan pada Lampiran 2, sedangkan secara agregatif disajikan dalam Tabel 1.

Tabel 1 memperlihatkan beberapa kenyataan berikut. 1. Penyusutan tangensial $\{\mathrm{Sh}(\mathrm{t})\}$ dipengaruhi secara sangat nyata oleh faktor komposisi konservan dan

Tabel 1. Hasil Analisis Varians Secara Agregatif

\begin{tabular}{|c|c|c|c|c|c|}
\hline \multirow[t]{2}{*}{ Sumber Variasi } & \multicolumn{5}{|c|}{ Parameter } \\
\hline & $\operatorname{Sh}(t)$ & $\operatorname{Sh}(r)$ & Ratio T/R & ASE T & ASE R \\
\hline Komposisi (A) & $* *$ & $* *$ & NS & ** & ** \\
\hline $\begin{array}{l}\text { Durasi Perendaman } \\
\text { (B) }\end{array}$ & ** & NS & NS & NS & NS \\
\hline Interaksi (A x B) & NS & ** & NS & NS & * \\
\hline
\end{tabular}

Keterangan: ns adalah tidak signifikan. * berarti signifikan, ** berarti sangat signifikan. 
durasi perendaman, tetapi tidak dipengaruhi oleh interaksi kedua faktor tersebut. 2. Penyusutan radial $\{\mathrm{Sh}(\mathrm{r})\}$ dipengaruhi secara sangat nyata, baik oleh interaksi antara komposisi konservan dan durasi perendaman, maupun faktor komposisi konservan, tetapi tidak dipengaruhi oleh faktor lama perendaman. 3. Rasio Penyusutan T/R tidak dipengaruhi oleh faktor komposisi konservan dan durasi perendaman, maupun interaksi keduanya. 4. Nilai ASE tangensial hanya dipengaruhi secara sangat nyata oleh faktor komposisi konservan. 5. Nilai ASE radial dipengaruhi secara nyata oleh interaksi antara faktor komposisi konservan dan durasi perendaman, bahkan dipengaruhi secara sangat nyata oleh faktor komposisi konservan.

Untuk mengetahui perbedaan penyusutan tangensial dalam aras komposisi konservan dan lama perendaman, dilakukan analisis LSD. Hasilnya disajikan berurutan pada Tabel 2 dan 3.

Berdasarkan Tabel 2 mengenai penyusutan tangensial, terlihat bahwa komposisi konservan A1 tidak berbeda terhadap A2, tetapi keduanya berbeda

\section{Tabel 2. Hasil Analisis LSD Pengaruh Komposisi Konservan Terhadap Penyusutan Tangensial}

\begin{tabular}{c|c|c}
$\begin{array}{c}\text { Komposisi Konservan Urea } \\
\text { Dibanding PEG 1000 (gram) }\end{array}$ & Rata-rata & $\begin{array}{c}\text { Nilai LSD } \\
(0,01)\end{array}$ \\
\hline A1 (10:10) & 4,02 a & \multirow{2}{*}{0,13} \\
\cline { 1 - 2 } A2 (20:10) & 3,93 a & \\
\cline { 1 - 2 } A3 (30:10) & $3,60 \mathrm{~b}$ &
\end{tabular}

Keterangan: nilai yang ditandai oleh huruf yang sama berarti nilai tersebut tidak berbeda

Tabel 3. Hasil Analisis LSD Pengaruh Lama Perendaman Terhadap Penyusutan Tangensial (\%)

\begin{tabular}{c|c|c} 
Lama Perendaman (hari) & Rata-rata & $\begin{array}{c}\text { Nilai LSD } \\
(0,01)\end{array}$ \\
\hline 1 & $3,95 \mathrm{a}$ & \multirow{2}{*}{0.13} \\
\cline { 1 - 2 } 3 & $3,84 \mathrm{ab}$ & \\
\hline 5 & $3,77 \mathrm{~b}$ &
\end{tabular}

Keterangan: nilai yang ditandai oleh huruf yang sama berarti nilai tersebut tidak berbeda secara sangat nyata terhadap komposisi konservan A3. Sementara itu, durasi perendaman selama tiga hari tidak berbeda terhadap durasi perendaman satu hari maupun lima hari, tetapi kedua durasi perendaman yang disebut terakhir itu berbeda secara sangat nyata terhadap durasi perendaman lima hari.

Untuk mengetahui perbedaan penyusutan radial dalam aras interaksi antara komposisi konservan dan lama perendaman, maka dilakukan analisis LSD. Hasilnya secara berurutan disajikan pada Tabel 4.

Berdasarkan Tabel 4 mengenai penyusutan radial, maka terlihat bahwa komposisi konservan A1 tidak berbeda terhadap A2, tetapi keduanya berbeda sangat nyata terhadap komposisi konservan A3. Sementara itu dalam konteks interaksi antara komposisi konservan dan durasi perendaman, terlihat bahwa interaksi antara komposisi A3 dan perendaman tiga hari mendapatkan nilai terendah $(2,54 \%)$, sedangkan interaksi antara komposisi A1 dan perendaman satu hari mendapatkan nilai tertinggi $(3,00 \%)$.

Untuk mengetahui perbedaan ASE penyusutan tangensial dalam aras komposisi konservan, maka dilakukan analisis LSD. Hasilnya disajikan pada Tabel 5 berikut.

Berdasarkan Tabel 5 terlihat bahwa komposisi konservan A1 (38,27\%) tidak berbeda terhadap komposisi konservan A2 (39,71\%), tetapi keduanya berbeda sangat nyata terhadap komposisi konservan A3 (44,74\%) dalam hal ASE tangensial.

Sebagaimana disajikan pada Tabel 1, nilai ASE Radial dipengaruhi secara nyata oleh interaksi antara faktor komposisi konservan dan durasi perendaman, dan dipengaruhi secara sangat nyata oleh faktor komposisi konservan. Oleh karena itu, perlu dilakukan analisis LSD untuk mengetahui perbedaan ASE radial dalam aras interaksi antara faktor komposisi konservan dan durasi

Tabel 4. Hasil Analisis LSD Pengaruh Interaksi Komposisi Konservan dan Durasi Perendaman

Terhadap Penyusutan Radial

\begin{tabular}{|c|c|c|c|c|c|}
\hline \multirow{2}{*}{$\begin{array}{l}\text { Komposisi Konservan Urea } \\
\text { Dibanding PEG } 1000 \text { (gram) }\end{array}$} & \multicolumn{3}{|c|}{ Durasi Perendaman } & \multirow{2}{*}{ Rata-rata } & \multirow{2}{*}{ Nilai LSD } \\
\hline & 1 Hari & 3 Hari & 5 Hari & & \\
\hline A1 (10:10) & $3,00 \mathrm{c}$ & $3,12 \mathrm{c}$ & $2,94 \mathrm{bc}$ & $3,02 x$ & \multirow[b]{2}{*}{$\left(A^{*} B\right) 0,01=0,19$} \\
\hline A2 (20:10) & $2,97 \mathrm{bc}$ & $3,07 \mathrm{c}$ & $2,94 \mathrm{bc}$ & $3,00 x$ & \\
\hline A3 $(30: 10)$ & $2,80 \mathrm{~b}$ & $2,54 \mathrm{a}$ & $2,78 \mathrm{~b}$ & 2,71 y & \multirow{2}{*}{$\mathrm{A} 0,01=0,11$} \\
\hline Rata-rata & $2,90 p$ & $2,91 p$ & $2,89 p$ & 2,90 & \\
\hline
\end{tabular}

Keterangan: nilai yang ditandai oleh huruf yang sama berarti nilai tersebut tidak berbeda 
Tabel 5. Analisis LSD Pengaruh Komposisi Konservan Terhadap

Nilai ASE Tangensial (\%)

\begin{tabular}{c|c|c}
$\begin{array}{c}\text { Komposisi Konservan Urea Dibanding } \\
\text { PEG 1000 (gram) }\end{array}$ & Rata-rata & $\begin{array}{c}\text { Nilai LSD } \\
(0,01)\end{array}$ \\
\hline A1 (10:10) & $38,27 \mathrm{a}$ & \multirow{2}{*}{2.03} \\
\hline A2 (20:10) & $39,71 \mathrm{a}$ & \\
\hline A3 (30:10) & $44,74 \mathrm{~b}$ &
\end{tabular}

Keterangan: nilai yang ditandai oleh huruf yang sama berarti nilai tersebut tidak berbeda

Tabel 6. Analisis LSD Pengaruh Interaksi Komposisi Konservan dan Durasi Perendaman Terhadap Nilai ASE Radial (\%)

\begin{tabular}{|c|c|c|c|c|c|}
\hline \multirow{2}{*}{$\begin{array}{l}\text { Komposisi Konservan Urea } \\
\text { Dibanding PEG } 1000 \text { (gram) }\end{array}$} & \multicolumn{3}{|c|}{ Durasi Perendaman } & \multirow{2}{*}{ Rata-rata } & \multirow{2}{*}{ Nilai LSD } \\
\hline & 1 Hari & 3 Hari & 5 Hari & & \\
\hline A1 (10:10) & $16,54 \mathrm{~b}$ & $13,36 \mathrm{a}$ & $17,63 \mathrm{~b}$ & $15,84 x$ & \multirow[b]{2}{*}{$\left(A^{*} B\right)_{0,05}=2,88$} \\
\hline A2 (20:10) & $17,67 \mathrm{~b}$ & $14,76 \mathrm{bc}$ & $18,10 \mathrm{~b}$ & $16,84 x$ & \\
\hline A3 (30:10) & $21,92 \mathrm{c}$ & $29,31 \mathrm{c}$ & $23,40 \mathrm{c}$ & $24,88 y$ & \multirow[b]{2}{*}{$A_{0,01}=3,94$} \\
\hline Rata-rata & $18,71 p$ & $19,14 p$ & $19,71 p$ & 19.19 & \\
\hline
\end{tabular}

Keterangan: nilai yang ditandai oleh huruf yang sama berarti nilai tersebut tidak berbeda

perendaman. Hasilnya disajikan pada Tabel 6.

Berdasarkan Tabel 6 tentang ASE radial, maka terlihat bahwa komposisi konservan A1 (15,84\%) tidak berbeda terhadap A2 (16,84\%), tetapi keduanya berbeda sangat nyata terhadap komposisi konservan A3 (24,88\%). Sementara itu, dalam konteks interaksi antara komposisi konservan dan durasi perendaman, terlihat bahwa interaksi antara komposisi A1 dan perendaman tiga hari mendapatkan nilai terendah (13,36\%), sedangkan interaksi antara A3 dan perendaman tiga hari mendapatkan nilai tertinggi $(29,31 \%)$.

\subsection{Pembahasan}

Dalam konteks penyusutan tangensial, Tabel 2 memperlihatkan bahwa komposisi bahan konservan A1, A2 dan A3 menghasilkan penyusutan masingmasing sebesar 4,02 dan 3,93 dan 3,60\%. Hal ini berarti bahwa semakin besar proporsi PEG 1000 di dalam larutan konservan, semakin rendah tingkat penyusutan tangensial. Dengan demikian, PEG-100 memperlihatkan semakin efektif untuk mencegah terjadinya penyusutan dalam arah tangensial. Keefektifan PEG sebagai bahan konservan ini seiring dengan hasil penelitian Hafors (2010), yang menyimpulkan bahwa PEG 600 memiliki effek pengurangan penyusutan kayu yang signifikan, apalagi PEG 1500 dan PEG 4000.

Sementara itu, Tabel 3 memperlihatkan, bahwa durasi perendaman 1, 3 dan 5 hari mengakibatkan penyusutan tangensial sebesar 3,95 dan 3,84 dan 3,77\%. Hal ini berarti bahwa semakin proses perendaman kayu di dalam larutan konservan, semakin rendah tingkat penyusutan tangensial. Hal ini dapat dipahami, karena semakin lama kayu direndam di dalam laruta konservan, maka akan mengakibatkan semakin banyak larutan bahan konservan yang terserap dan beremayan di dalam kayu. Hal ini mengakibatkan semakin efektif totalitas larutan konservan itu mencegah terjadinya penyusutan tangensial.

Tabel 4 menunjukkan bahwa semakin lama proses perendaman kayu di dalam larutan konservan, semakin rendah tingkat penyusutan radial. Semakin banyak larutan bahan konservan terserap dan beremayan di dalam kayu, sehingga efektif mencegah terjadinya penyusutan radial.

Dalam konteks penyusutan radial, Tabel 4 memperlihatkan bahwa interaksi faktor komposisi konservan dan durasi perendaman berpengaruh secara positif terhadap penyusutan radial. Interaksi komposisi konservan A3 dan perendaman 3 hari menghasilkan penyusutan radial terkecil, yaitu 2,54\%, sedangkan interaksi antara komposisi konservan A1 dan perendaman 3 hari menghasilkan penyusutan radial paling besar, yaitu 3,12\%. Hal ini berarti bahwa semakin banyak proporsi urea bersama dengan semakin lama proses perendaman 
kayu di dalam larutan konservan, semakin rendah tingkat penyusutan radial. Hal ini menunjukkan bahwa semakin banyak larutan bahan konservan terserap dan bersemayan di dalam kayu, sehingga efektif mencegah terjadinya penyusutan radial. Pada saat yang sama, data ini juga mengindikasikan, bahwa semakin banyak proporsi urea di dalam bahan konservan, semakin efektif bahan konservan ini mencegah terjadinya penyusutan kayu arah radial.

Dalam konteks parameter ASE tangensial, Tabel 5 memperlihatkan bahwa komposisi bahan konservan A1, A2 dan A3 menghasilkan nilai masing-masing sebesar 38,27 dan 39,71 serta 44,74\%. Hal ini berarti bawah semakin besar proporsi urea di dalam larutan konservan, semakin tinggi tingkat nilai ASE tangensial. Dengan demikian, effektivitas anti penyusutan tangensial semakin baik. Hal ini berarti pula bahwa keberadaan urea yang semakin besar di dalam di dalam PEG yang konstan semakin efektif meningkatkan kestabilan dimensi kayu. Hal ini disebabkan gugus-gugus amina $\left(-\mathrm{NH}_{2}\right)$ yang semula merupakan bagian dari mulekul urea itu kemudian bereaksi dengan selulosa dengan cara mengganti atom $\mathrm{H}$ melalui ikatan hydrogen, dan mengganti gugus hidroksil $(-\mathrm{OH})$ melalui ikatan asetal. Dengan demikian, semakin banyak urea, semakin banyak gugus amina, dan semakin banyak pula atom hydrogen dan gugus hidroksil di dalam mulekul selulosa yang diganti oleh gugus amina. Penggantian yang semakin banyak ini mengakibatkan semakin tinggi tingkat kemampunannya untuk menahan gerakan penyusutan melalui tiga model mekanisme, yaitu (1) menghalangi penyerapan air (2) menghasilkan hubungan silang antara kelompok hidroksil, dan (3) menghalangi perubahan dimensi kayu dengan cara penahanan pada tingkat sel.
Dalam konteks parameter ASE radial, Tabel 6 memperlihatkan bahwa interaksi faktor komposisi konservan dan durasi perendaman berpengaruh secara positif terhadap nilai ASE radial. Interaksi antara komposisi konservan A3 dan durasi perendaman 3 hari, menghasilkan nilai tertinggi, yaitu 29,31\%. Sebaliknya, interaksi antara komposisi konservan A1 dan durasi perendaman 3 hari, menghasilkan nilai terendah, yaitu 13,36\%. Hal ini mengindikasikan, bahwa semakin banyak proporsi urea bersama dengan proses perendaman kayu perendaman selama 3 hari di dalam larutan konservan, semakin tinggi tingkat nilai ASE radial. Dengan demikian, efisiensi daya menahan terjadinya penyusutan arah radial kayu semakin besar. Hal ini mengindikasikan, bahwa semakin banyak proporsi urea di dalam larutan bahan konservan bersama dengan PEG 1000, semakin besar nilai ASE radial. Dengan demikian, kayu menjadi semakin stabil dimensinya dan semakin efektif mencegah terjadinya kerusakan kayu.

Dalam konteks parameter jumlah retak dan panjang retak, Lampiran 1 memperlihatkan bahwa kayu yang tidak dikenai perlakukan konservasi dengan bahan konservan memiliki retak sebanyak 2,42 buah dengan panjang retak rata-rata $26,20 \mathrm{~mm}$. Sementara itu, jumlah retak dan panjang retak pada kayu yang diberi perlakukan dengan bahan konservan dengan komposisi A1 adalah 1,44 buah dan 23,22 mm, komposisi A2 adalah 1 buah dan 3,43 mm, bahkan pada komposisi A3 tidak terjadi retak sama sekali pada kayu yang diperlakukan. Dengan demikian, maka semakin banyak bahan aktif urea dan PEG 1000 yang terkandung dalam bahan konservan mengakibatkan semakin efektif untuk mencegah terjadinya retak dan semakin memperpendek dimensi panjang retak.

\section{Lampiran 1. Data Hasil Penelitian Secara Agregatif}

\begin{tabular}{|c|c|c|c|c|c|c|c|c|c|}
\hline \multicolumn{2}{|c|}{ Perlakuan } & \multirow[b]{2}{*}{ Ulangan } & \multicolumn{7}{|c|}{ Parameter } \\
\hline $\begin{array}{l}\text { Komposisi } \\
\text { Konservan } \\
\text { Urea: PEG } 1000\end{array}$ & $\begin{array}{l}\text { Durasi } \\
\text { Perendaman } \\
\text { (hari) }\end{array}$ & & 1 & 2 & 3 & 4 & 5 & 6 & 7 \\
\hline \multirow[t]{8}{*}{ Kontrol } & 1 & 1 & 6,72 & 3,59 & 2,01 & 0 & 0 & 2 & 9,42 \\
\hline & & 2 & 6,52 & 3,62 & 1,83 & 0 & 0 & 1 & 7,14 \\
\hline & & 3 & 6,51 & 3,56 & 1,89 & 0 & 0 & 4 & 25,54 \\
\hline & 3 & 1 & 6,59 & 3,60 & 1,85 & 0 & 0 & 4 & 66,23 \\
\hline & & 2 & 6,40 & 3,63 & 1,79 & 0 & 0 & 2 & 22,86 \\
\hline & & 3 & 6,51 & 3,56 & 1,89 & 0 & 0 & 3 & 52,30 \\
\hline & 5 & 1 & 6,49 & 3,60 & 1,86 & 0 & 0 & 6 & 30,47 \\
\hline & & 2 & 6,47 & 3,57 & 1,86 & 0 & 0 & 0 & 0 \\
\hline
\end{tabular}




\begin{tabular}{|c|c|c|c|c|c|c|c|c|c|}
\hline & & 3 & 6,41 & 3,72 & 1,88 & 0 & 0 & 0 & 0 \\
\hline \multirow[t]{9}{*}{ A1 $(10: 10)$} & 1 & 1 & 4,17 & 2,87 & 1,48 & 37,97 & 20,27 & 3 & 14,43 \\
\hline & & 2 & 4,21 & 3,05 & 1,42 & 35,49 & 15,72 & 2 & 9,12 \\
\hline & & 3 & 3,98 & 3,07 & 1,33 & 38,84 & 13,61 & - & - \\
\hline & 3 & 1 & 3,95 & 3,16 & 1,29 & 40,04 & 12,13 & 2 & 6,32 \\
\hline & & 2 & 3,87 & 3,03 & 1,34 & 39,60 & 16,50 & 1 & 4,20 \\
\hline & & 3 & 4,08 & 3,15 & 1,33 & 37,36 & 11,45 & 2 & 16,26 \\
\hline & 5 & 1 & 3,98 & 3,04 & 1,39 & 38,67 & 15,59 & 1 & 7,20 \\
\hline & & 2 & 3,95 & 2,91 & 1,38 & 38,93 & 18,62 & - & - \\
\hline & & 3 & 4,00 & 2,87 & 1,47 & 37,53 & 22,81 & 2 & 12,13 \\
\hline \multirow[t]{9}{*}{ A2 $(20: 10)$} & 1 & 1 & 3,96 & 2,93 & 1,42 & 41,10 & 18,53 & 2 & 11,32 \\
\hline & & 2 & 3,95 & 3,03 & 1,34 & 39,51 & 16,48 & 1 & 6,65 \\
\hline & & 3 & 3,93 & 2,95 & 1,36 & 39,69 & 18,02 & 1 & 5,12 \\
\hline & 3 & 1 & 3,95 & 3,03 & 1,31 & 40,09 & 15,81 & 1 & 2,43 \\
\hline & & 2 & 4,03 & 3,14 & 1,35 & 37,06 & 13,48 & - & - \\
\hline & & 3 & 4,09 & 3,03 & 1,36 & 37,22 & 14,97 & 2 & 5,32 \\
\hline & 5 & 1 & 3,83 & 3,02 & 1,36 & 41,05 & 16,23 & - & - \\
\hline & & 2 & 3,79 & 2,30 & 1,29 & 40,39 & 16,25 & - & - \\
\hline & & 3 & 3,83 & 2,91 & 1,47 & 40,32 & 21,84 & - & - \\
\hline \multirow[t]{9}{*}{ A3 $(30: 10)$} & 1 & 1 & 3,96 & 2,84 & 1,44 & 41,06 & 21,03 & - & - \\
\hline & & 2 & 3,66 & 3,91 & 1,28 & 43,89 & 19,76 & - & - \\
\hline & & 3 & 3,71 & 2,67 & 1,44 & 43,03 & 24,98 & - & - \\
\hline & 3 & 1 & 3,53 & 2,56 & 1,38 & 46,48 & 28,77 & - & - \\
\hline & & 2 & 3,55 & 2,48 & 1,61 & 44,58 & 31,71 & - & - \\
\hline & & 3 & 3,49 & 2,58 & 1,39 & 46,43 & 27,46 & - & - \\
\hline & 5 & 1 & 3,32 & 2,76 & 1,21 & 48,85 & 23,45 & - & - \\
\hline & & 2 & 3,60 & 2,76 & 1,31 & 44,41 & 22,85 & - & - \\
\hline & & 3 & 3,59 & 2,83 & 1,32 & 43,95 & 23,91 & - & - \\
\hline
\end{tabular}

Keterangan :

1. Penyusutan Tangensial (\%)

2. Penyusutan Radial (\%)

3. Ratio $T / R$

4. ASE T

5. ASE R

6. Jumlah retak

7. Panjang retak $(\mathrm{mm})$

Lampiran 2. Analisis Varians

\begin{tabular}{|c|c|c|c|c|c|c|}
\hline \multirow[t]{2}{*}{ Sumber Variasi } & Derajat & Jumlah & Rata-rata & F hitung & Probabilitas & \\
\hline & Bebas & Kuadrat & Kuadrat & & & \\
\hline \multicolumn{6}{|c|}{ Penyusutan Tangensial } & \\
\hline A & 2 & 0,879 & 0,440 & $46,537 * *$ & 0,000 & \\
\hline B & 2 & 0,149 & 0,074 & $47,874 * *$ & 0,003 & \\
\hline$A * B$ & 4 & 0,100 & 0,025 & $2,643 n s$ & 0,068 & \\
\hline Error & 18 & 0,170 & 0,009 & & & \\
\hline Total & 26 & 1,298 & & & & \\
\hline \multicolumn{7}{|c|}{ Penyusutan Radial } \\
\hline$A$ & 2 & 0,544 & 0,272 & $43,273^{* *}$ & 0,000 & \\
\hline B & 2 & 0,003 & 0,001 & $0,202 n s$ & 0,819 & \\
\hline$A * B$ & 4 & 0,190 & 0,048 & $7,575^{* *}$ & 0,001 & \\
\hline Error & 18 & 0,113 & 0,006 & & & \\
\hline Total & 26 & 0,850 & & & & \\
\hline \multicolumn{7}{|c|}{ Ratio Penyusutan $T / R$} \\
\hline $\mathrm{A}$ & 2 & 0,007 & 0,003 & $0,604 n s$ & 0,557 & \\
\hline B & 2 & 0,002 & 0,001 & $0,219 \mathrm{~ns}$ & 0,805 & \\
\hline$A * B$ & 4 & 0,062 & 0,016 & $2,762 n s$ & 0,600 & \\
\hline Error & 18 & 0,101 & 0,006 & & & \\
\hline Total & 26 & 0,173 & & & & \\
\hline \multicolumn{7}{|l|}{ ASET } \\
\hline A & 2 & 207,781 & 103,890 & $46,312^{* *}$ & 0,000 & \\
\hline B & 2 & 11,778 & 5,889 & $2,625 n s$ & 0,100 & \\
\hline$A * B$ & 4 & 23,856 & 5,964 & $2,659 n s$ & 0,067 & \\
\hline Error & 18 & 40,379 & 2,243 & & & \\
\hline Total & 26 & 283,793 & & & & \\
\hline \multicolumn{7}{|l|}{ ASE R } \\
\hline A & 2 & 452,678 & 226,339 & $26,866^{* *}$ & 0,000 & \multirow{5}{*}{$\begin{array}{l}\text { Keterangan: ns berarti tidak berbeda. * } \\
\text { berarti berbeda signifikan, }{ }^{* *} \text { berarti berbeda } \\
\text { sangat signifikan. }\end{array}$} \\
\hline$B$ & 2 & 28,440 & 14,220 & $1,688 \mathrm{~ns}$ & 0,213 & \\
\hline$A * B$ & 4 & 120,706 & 30,177 & $3,582^{*}$ & 0,026 & \\
\hline Error & 18 & 151,643 & 8,425 & & & \\
\hline Total & 26 & 753,467 & & & & \\
\hline
\end{tabular}




\section{KESIMPULAN DAN SARAN}

Kesimpulan yang diperoleh disajikan dalam beberapa butir sebagai berikut.

1. Komposisi bahan konservan mempengaruhi penyusutan tangensial, penyusutan radial, ASE tangensial dan ASE radial. Semakin tinggi proporsi urea di dalam larutan bahan konservan yang mengadung PEG 1000 dalam jumlah yang tetap, kayu yang dikonservasi memiliki penyusutan tangensial dan penyusutan radial yang semakin rendah, sebaliknya kayu itu memiliki ASE tangensial dan ASE radial yang semakin tinggi.

2. Lama perendaman kayu di dalam bahan konservan hanya mempengaruhi penyusutan tangensial. Semakin lama durasi perendaman kayu di dalam larutan bahan konservan, kayu yang dikonservasi memiliki penyusutan tangensial yang semakin rendah.

\section{DAFTAR PUSTAKA}

Cahyandaru, N., Swastikawati, A., Brahmantara., Kusumawati, H., Atmaja, Y., Priyanto, A., dan Pramudianto, 2010. Laporan Hasil Kajian Konservasi Dan Konsep Pengembangan Perahu Kuno Rembang. Balai Konservasi Peninggalan Borobudur, Direktorat Jenderal Sejarah Dan Purbakala Kementerian Kebudayaan Dan Pariwisata. Magelang.

Fernando dan Prayitno, 1999. Pengaruh Perbandingan Campuran Urea dan PEG 1000 serta Lama Perendaman terhadap Kestabilan Dimensi kayu Suren (Toona sureni Merr). Buletin Kehutanan 39:56- 57.

Hafors, B., 2010. Conservation of The Wood of Swedish Warship Vasa of A.D 1628: Evaluation of Polyetilen Glycol Conservation Programmes. Disertation. Department of Conservation. Faculty of Science, Goteborgs Universitet. Swedish.

Kollman F.F.P., Kuenzi, E.W., dan Stamm, A.J., 2012. Principle of Wood Science and Technology. Volume II. Wood Based Material. SpringerVerlag. New York Inc.

Kusumawati, Yudi Atmaja, dan Sri Wahyuni, 2009. Konservasi Kapal Kuno Rembang, Laporan
3. Interaksi antara komposisi bahan konservan dan durasiperendaman berpengaruhterhadap penyusutan radial dan nilai ASE radial. Bahan konservan yang mengandung proporsi urea yang semakin tinggi berinteraksi dengan durasi waktu perendaman yang semakin lama cenderung menghasilkan penyusutan radial yang semakin rendah dan nilai ASE radial yang semakin tinggi.

Sebuah saran dapat disampaikan, yaitu bahwa urea perlu dipertimbangkan sebagai bahan konservan untuk dicampur dengan PEG 1000 untuk mengkonservasi benda cagar budaya berbahan kayu maritim. Meskipun demikian, diperlukan kajian lebih lanjut untuk membuktikan apakah penggunaan urea ini tidak mengubah secara signifikan sifat-sifat kayu maritime

Studi, Balai Konservasi Peninggalan Borobudur, Direktorat Jenderal Sejarah Dan Purbakala Kementerian Kebudayaan Dan Pariwisata. Magelang.

Noer, A., 2001. Variasi Sifat Fisika dan Sifat Mekanika Kayu Warugombong (Hibiscus macrophyllus) Pada Arah Radial dan Aksial. Skripsi. Fakultas kehutanan Institut Pertanian Intan. YogyakartaSetiawan, O., 2001. Sifat Kimia dan Dimensi Serat Kayu Tisuk pada Arah Aksial dan Radial. Skripsi. Fakultas kehutanan Institut Pertanian Intan. Yogyakarta.

Shmulsky, R dan Jones, D., 2011. Forest Product and Wood Science. An Introduction. 6 edition. Wiley-Blackwell Publication. United Kingdom.

Widianto, H., 2015. Kebijakan Pelestarian Cagar Budaya, Khususnya Konservasii Cagar Budaya Bawah Air. Makalah Direktur Direktorat Pelestarian Cagar Budaya dan Permuseuman disampaikan pada Workshop Konservasi Watterlogged Wood. Rembang. 